International Journal of Advanced Technology in Mechanical, Mechatronics and Materials
(IJATEC)
Vol. 02, No. 2 (2021) 61-69
Institute for Research on Innovation and Industrial System (IRIS)

\title{
Design and Wheel Torque Performance Test of The Electric Racing Car Concept E-Falco
}

\author{
Hadi Pranoto*a, Bambang Darmono, Zainal Arifin ${ }^{\mathrm{b}}$, Ibnu Susanto ${ }^{\mathrm{b}}$ \\ aFaculty of Engineering, Universitas Mercu Buana, Jakarta, Indonesia \\ ${ }^{b}$ Department of Mechanical Engineering, Universitas Mercu Buana, Jakarta, Indonesia
}

\begin{abstract}
To reduce the use of fossil fuels in vehicles and reduce exhaust emissions, it is necessary to use electric vehicle technology. A good electric car design is carried out with the aim of creating an electric car that is safe, strong, efficient, and has good performance. The frame and body of the EFalco electric car are designed using SolidWorks software. The strength of the frame structure material is simulated using ANSYS software and gets the safety factor of 15 . The air drag of the car body aerodynamic is simulated by CFD software and the result of air drag force at the speed of 10 $\mathrm{km} / \mathrm{h}$ is $0.47 \mathrm{~N}$, a speed of $20 \mathrm{~km} / \mathrm{h}$ is $1.90 \mathrm{~N}$, and a speed of $40 \mathrm{~km} / \mathrm{h}$ is $7.48 \mathrm{~N}$. The dyno test is performed to know how much the wheel torque of the E-Falco electric car. The wheel torque based on the dyno test at speed of $1 \mathrm{~km} / \mathrm{h}$ is $2 \mathrm{Nm}$, speed of $10 \mathrm{~km} / \mathrm{h}$ is $160 \mathrm{Nm}$, speed of $20 \mathrm{~km} / \mathrm{h}$ is 275 $\mathrm{Nm}$, speed of $30 \mathrm{~km} / \mathrm{h}$ is $268 \mathrm{Nm}$, speed of $40 \mathrm{~km} / \mathrm{h}$ is $230 \mathrm{Nm}$, speed of $50 \mathrm{~km} / \mathrm{h}$ is $178 \mathrm{Nm}$, speed of $60 \mathrm{~km} / \mathrm{h}$ is $138 \mathrm{Nm}$, and speed of $70 \mathrm{~km} / \mathrm{h}$ is $104 \mathrm{Nm}$. The peak wheel torque occurs at a speed of $13 \mathrm{~km} / \mathrm{h}$ is $279 \mathrm{Nm}$.
\end{abstract}

Keywords: motor; air drag; torque; speed; power

DOI: $10.37869 /$ ijatec.v2i2.45

Received 21 May 2021; Accepted 13 September 2021; Available online 18 November 2021

(C) The Authors. Published by IRIS. This is an open access article under the CC BY-NC-SA license cc) (1) (2)

\section{Introduction}

The transportation sector has continuously innovated and developed electric vehicle technology to reduce dependence on the use of fuel oil so that it is beneficial to reduce pollution and greenhouse gas emissions [1]. The main energy source used to rotate an electric car is a battery whose performance is very important for its effect on the safety, efficiency, and economy of the operation of electric vehicles [2].

To maximize the efficiency of electrical energy from the weight of the vehicle, the aerodynamic drag and rolling resistance must be minimized, while maximizing the efficiency of the motor and transmission, so it is important to design high-efficiency electric vehicles and in the design, it requires flexibility in placing components on electric vehicles to optimize weight positioning and minimize aerodynamic drag [3]. The obstacles experienced by an electric vehicle while running are road surface resistance, air drag, acceleration resistance, and uphill resistance [4].

After knowing that the electric car being designed must have high efficiency and taking into account the factors as described above, before doing the design it is necessary to know the type of car frame to be designed [5].

The type of frame that is often used in making electric cars is the tubular space frame because it has the advantage of being easy to manufacture and easy to repair so that the tubular space frame is the most favorite choice for the development of university-level competition racing cars [6] . 
The propulsion motor used in the E-Falco electric car is a BLDC motor with a power of $2 \mathrm{~kW}$ [7]. BLDC motor is a type of DC motor that does not use a brush, so it does not require brush replacement maintenance and this motor has many advantages such as high efficiency, high power, high torque to energy ratio, high-speed operation, simple driving method, and low cost [8].

The motor speed-torque characteristic of an electric vehicle shows that when the motor speed is still low, the motor will produce high torque and when the motor speed is higher, the torque produced by the motor will decrease [9]. The amount of torque produced by the wheels is equal to the torque of the motor multiplied by the ratio between the driven gears and the driver gears in the transmission system [10].

\section{Methodology}

The method to design the body and frame of electric vehicle E-Falco is using SolidWorks software, to know the amount of air drag force to the front car body is using the CFD software, and to determine the amount of wheel torque with variations in speed is using torque calculation and using a Dynotest.

\subsection{Designing the Frame and Body}

The frame and body of the E-Falco electric car are designed using SolidWorks software. The results of the tubular space frame design for the E-Falco electric car are as follows:

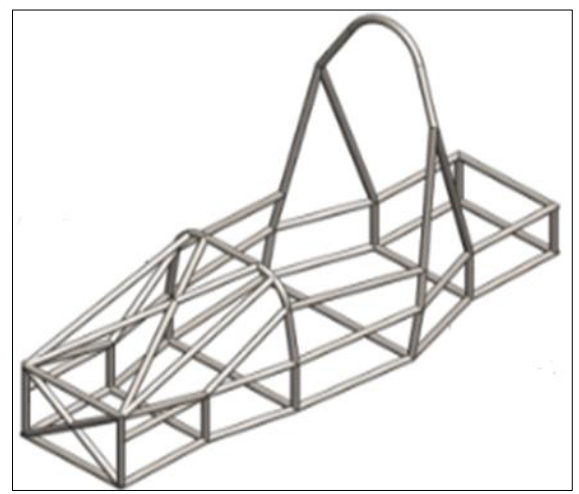

Figure 1. The geometry of the E - Falco electric car frame design

Below table is the frame dimension of electric car E-Falco:

Table 1. Frame dimensions

\begin{tabular}{lc}
\hline \multicolumn{1}{c}{ Parameter } & Dimensions (mm) \\
\hline Length & 2170 \\
Width & 740 \\
Front roll bar height & 600 \\
Rear roll bar height & 1180 \\
\hline
\end{tabular}

To find out and the strength of the frame structure material, it is simulated using ANSYS software so that the safety factor of the frame strength is known. The frame for this E-Falco electric car uses ASTM A36 material with a load of $243 \mathrm{~kg}$ and the results of the ANSYS simulation produce a safety factor of 15.

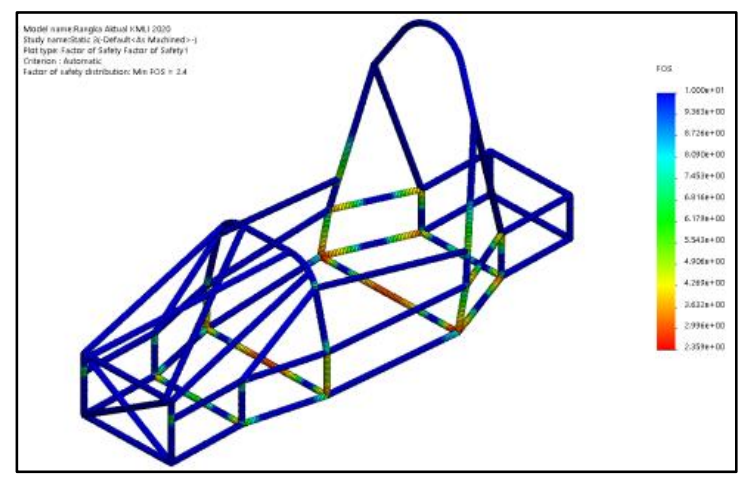

Figure 2. Simulation results of the safety factor calculation on ASTM A36 material 
The body of the E-Falco electric car is designed with the purpose to reduce the air drag coefficient as much as possible to reduce the load on the motor and save the use of electrical energy from the battery. The material used to make the E-Falco electric car body is fiberglass which has strong and lightweight properties.

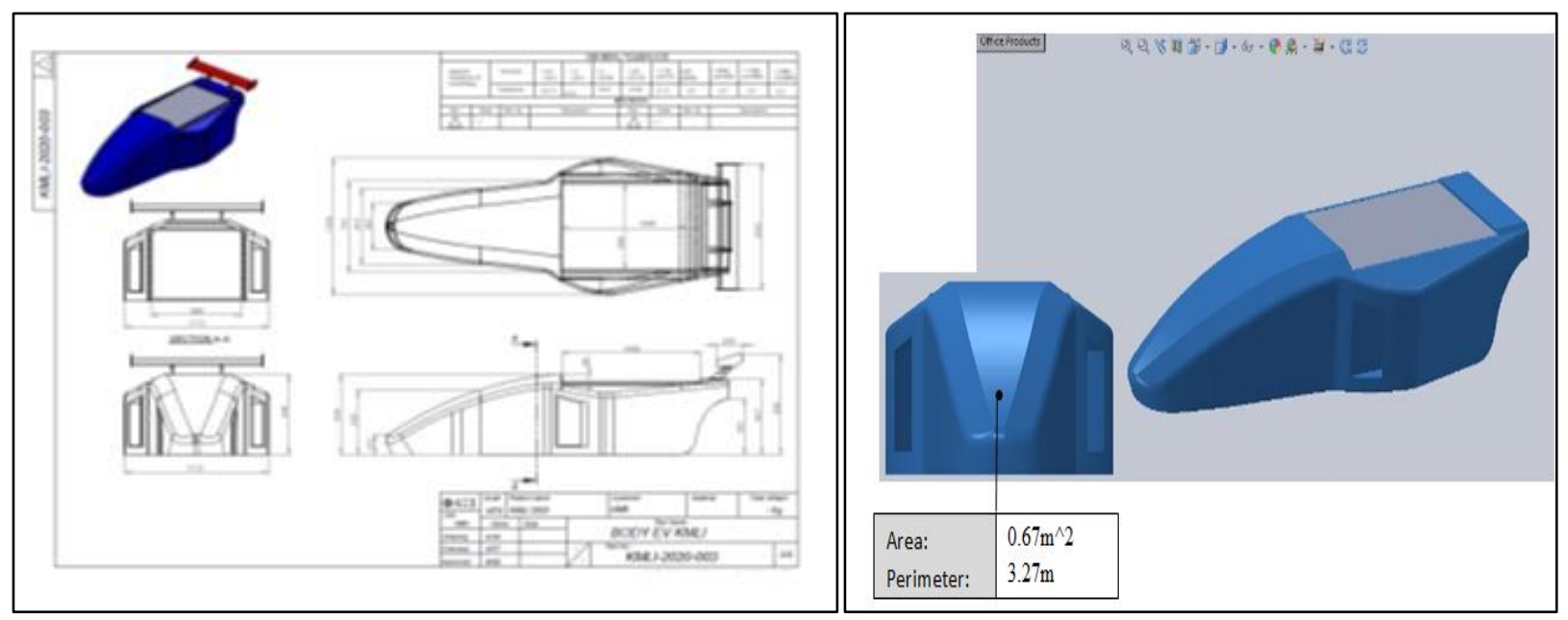

Figure 3. Design the body size of the E-Falco car

Below table is the body dimension of electric car E-Falco:

Table 2. Body dimensions

\begin{tabular}{lc}
\hline \multicolumn{1}{c}{ Parameter } & Dimension $(\mathrm{mm})$ \\
\hline Panjang & 2484 \\
Lebar & 836 \\
Tinggi & 610 \\
\hline
\end{tabular}

The results of the body design then analyzed how much the air drag coefficient using CFD software so that the air streamlines flow pattern is known which passes the body of the E-Falco Electric car.

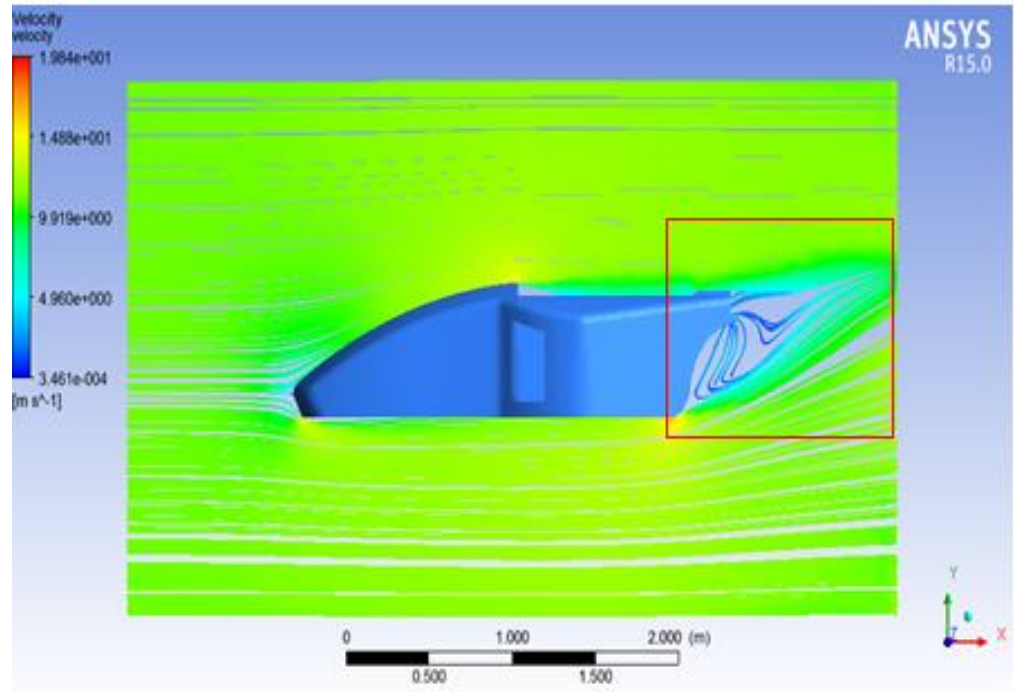

Figure 4. The streamlined flow pattern on the car body

\subsection{Components Assembly}

After making the car frame and body according to the design, then the E-Falco electric car components are assembled, such as the suspension system, brakes, steering, power transfer, motor, battery, controller, and other electrical systems. 

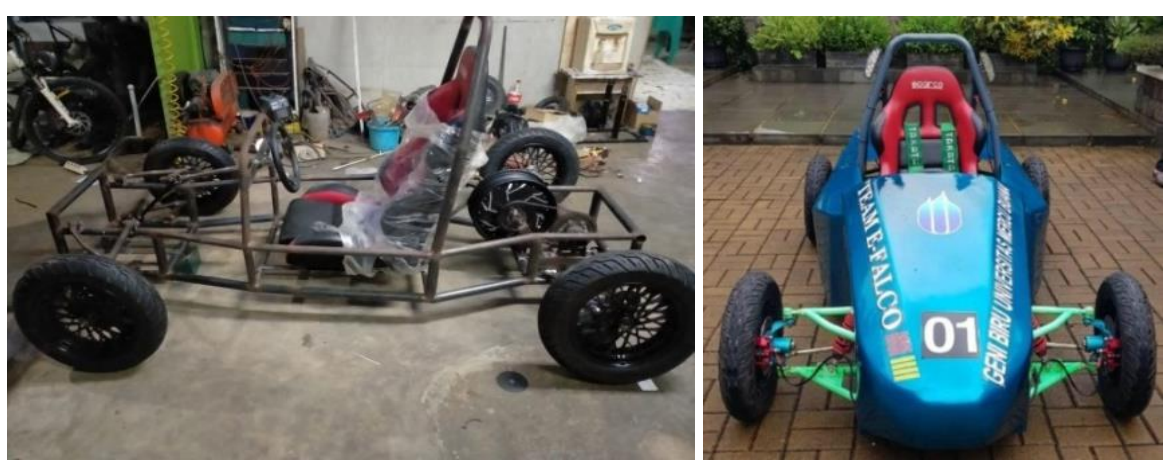

Figure 5. Assembling the components

Below table is the dimension data of electric car E-Falco:

Table 3. Car dimensions

\begin{tabular}{lc}
\hline \multicolumn{1}{c}{ Parameter } & Dimensions (mm) \\
\hline Length & 2484 \\
Width & 1340 \\
Height & 700 \\
Ground clearance & 100 \\
Wheelbase & 1690 \\
Thread & 1240 \\
Diameter of wheel & 500 \\
\hline
\end{tabular}

\subsection{Whell Torque Test Using Dynamometer Machine}

The wheel torque can be tested using the dynamometer chassis, which measures the output torque on the wheels.
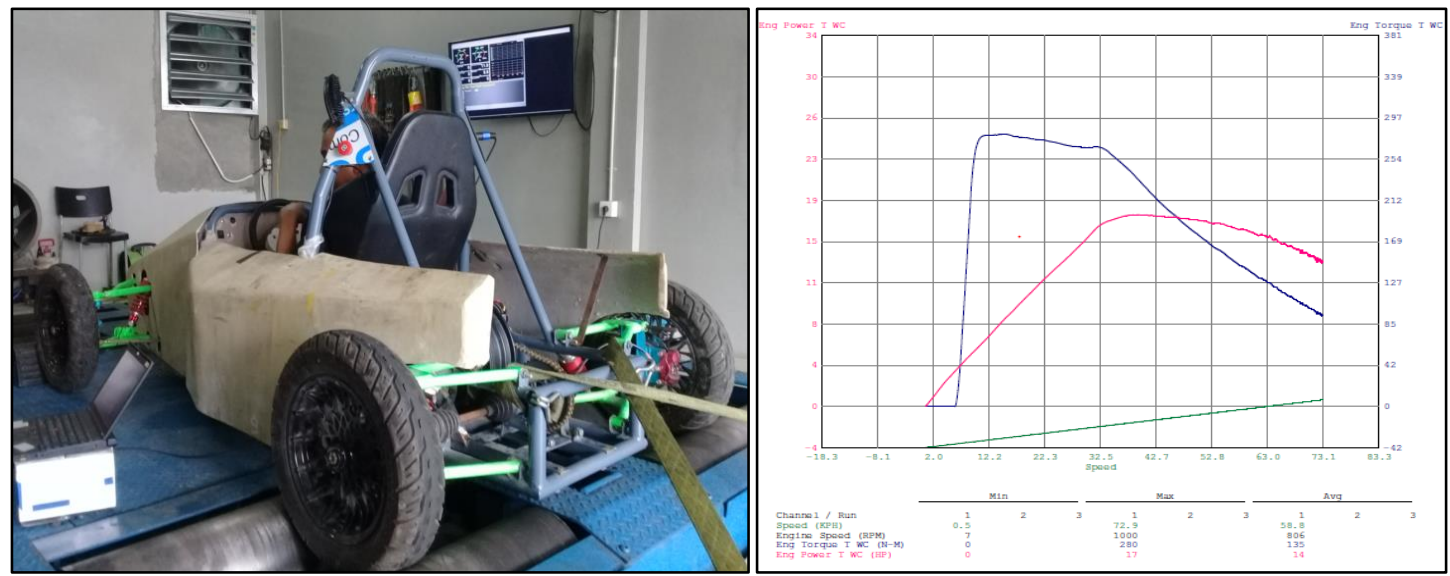

Figure 6. Dynotest

The above Bluetooth icons and parameters serve to send data from the conveyor to the robot arm according to the mailbox, where mailbox 1 is set to red.

Below table is the data of wheel torque as Dynotest result:

Table 4. Wheel torque

\begin{tabular}{ccccc}
\hline $\begin{array}{c}\text { Travel time } \\
(\mathrm{s})\end{array}$ & $\begin{array}{c}\text { Speed } \\
(\mathrm{m} / \mathrm{s})\end{array}$ & $\begin{array}{c}\text { Wheel rotation } \\
(\mathrm{rpm})\end{array}$ & $\begin{array}{c}\text { Wheel torque } \\
(\mathrm{Nm})\end{array}$ & $\begin{array}{c}\text { Power on the wheel } \\
\text { (hp) }\end{array}$ \\
\hline 0,00 & 0,5 & 7 & 0 & 0 \\
0,50 & 6,6 & 89 & 25 & 4 \\
1,00 & 13,0 & 177 & 279 & 7 \\
1,50 & 19,3 & 263 & 276 & 10 \\
2,00 & 25,3 & 346 & 270 & 13 \\
2,50 & 31,0 & 424 & 267 & 16 \\
\hline
\end{tabular}




\begin{tabular}{lllll}
\hline 3,00 & 36,4 & 498 & 250 & 17 \\
3,50 & 41,0 & 561 & 224 & 17 \\
4,00 & 44,8 & 613 & 202 & 17 \\
4,50 & 48,0 & 658 & 187 & 17 \\
5,00 & 50,9 & 697 & 174 & 17 \\
5,50 & 53,3 & 731 & 163 & 17 \\
6,00 & 55,5 & 760 & 155 & 16 \\
6,50 & 57,4 & 786 & 147 & 16 \\
7,00 & 59,1 & 810 & 142 & 16 \\
7,50 & 60,6 & 830 & 136 & 16 \\
8,00 & 61,9 & 849 & 132 & 16 \\
8,50 & 63,1 & 865 & 127 & 15 \\
9,00 & 64,2 & 880 & 123 & 15 \\
9,50 & 65,2 & 893 & 119 & 15 \\
10,00 & 66,0 & 905 & 117 & 15 \\
10,50 & 66,8 & 915 & 114 & 15 \\
11,00 & 67,4 & 925 & 112 & 15 \\
11,50 & 68,1 & 933 & 110 & 14 \\
12,00 & 68,6 & 941 & 108 & 14 \\
12,50 & 69,1 & 947 & 106 & 14 \\
13,00 & 69,5 & 953 & 104 & 14 \\
13,50 & 69,9 & 959 & 104 & 14 \\
14,00 & 70,3 & 964 & 102 & 14 \\
14,50 & 70,6 & 968 & 101 & 14 \\
15,00 & 70,9 & 972 & 101 & 14 \\
\hline
\end{tabular}

\subsection{Air Drag and Wheel Torque Calculation}

The purpose of air drag and wheel torque calculation is to compare the equation result and the test by CFD software for air drag and the dyno test for wheel torque. Below is the equation to calculate the air drag from the front car body and wheel torque:

- Resistance force of air drag

$$
\mathrm{F}_{\mathrm{air}}=0.5 \cdot \rho \cdot A \cdot \mathrm{C}_{\mathrm{d}} \cdot \mathrm{v}^{2}
$$

Where $\rho$ is density of air $\left(\mathrm{kg} / \mathrm{m}^{3}\right)$, A is frontal area $\left(\mathrm{m}^{2}\right), \mathrm{Cd}$ is air resistance coefficient, and $\mathrm{v}$ is vehicle speed $(\mathrm{m} / \mathrm{s})$.

The air drag calculation in this research is in the speed of $10 \mathrm{~km} / \mathrm{h}, 20 \mathrm{~km} / \mathrm{h}$, and $40 \mathrm{~km} / \mathrm{h}$. The literature has given the information that the E-Falco car model has a number air density is 1.25 $\mathrm{kg} / \mathrm{m} 3$, and the air resistance coefficient is 0.19 .

$$
\mathrm{F}_{\mathrm{air}}=0.5 \cdot(1.25) \cdot(0.51) \cdot(0.19) \cdot(2.8)^{2}=0.47 \mathrm{~N}
$$

- Whell torque

$$
\begin{aligned}
& \mathrm{F}=\mathrm{m} \cdot \mathrm{a} \\
& \mathrm{T}_{\mathrm{L}}=\mathrm{F} \cdot \mathrm{r}
\end{aligned}
$$

Where $F$ is force $(N), m$ is total mass $(\mathrm{kg})$, a is acceleration $\left(\mathrm{m} / \mathrm{s}^{2}\right), \mathrm{r}$ is wheel radius $(\mathrm{m})$, and $\mathrm{T}_{\mathrm{L}}$ is wheel torque $(\mathrm{Nm})$.

The data has got from the car and found that the mass of electric car is $188 \mathrm{~kg}$, the mass of driver is $55 \mathrm{~kg}$, and the wheel radius is $0.25 \mathrm{~m}$. The acceleration travel time is based on the travel time on the results of the dyno test and by using the interpolation formula it can be obtained the acceleration travel time according to the speed under research.

Table 5. Travel Time According to the Speed Variations

\begin{tabular}{cc}
$\begin{array}{c}\text { Vehicle Speed } \\
(\mathrm{km} / \mathrm{h})\end{array}$ & $\begin{array}{c}\text { Travel time of acceleration } \\
(\mathrm{s})\end{array}$ \\
\hline 0 to 1 & 0.04 \\
\hline
\end{tabular}




\begin{tabular}{lc}
\hline 0 to 10 & 0.77 \\
0 to 13 & 1.00 \\
0 to 20 & 1.56 \\
0 to 30 & 2.41 \\
0 to 40 & 3.40 \\
0 to 50 & 4.84 \\
0 to 60 & 7.30 \\
0 to 70 & 13.63 \\
\hline
\end{tabular}

The wheel torque calculation based on the vehicle acceleration starts from the speed of $1 \mathrm{~km} / \mathrm{h}=$ $0.28 \mathrm{~m} / \mathrm{s}$.

$$
\begin{aligned}
\mathrm{a} & =\frac{(0.28)-(0)}{(0.04)-(0)}=7 \mathrm{~m} / \mathrm{s}^{2} \\
\mathrm{~F} & =(243) \cdot(7)=1701 \mathrm{~N} \\
\mathrm{~T}_{\mathrm{L}} & =(1701) \cdot(0.25)=425 \mathrm{Nm}
\end{aligned}
$$

\section{Result and Analysis}

\subsection{Frame Safety Factor and Force of Air Drag}

The strength of the frame structure simulated using ANSYS software the safety factor of the frame with a load of $243 \mathrm{~kg}$ is 15 . From the simulation using the appropriate CFD software, it is shown in the figure 4 the drag of the air when the E-Falco car is driving with variations in speed is shown in table 4 below:

Table 6. Air drag force

\begin{tabular}{cc}
\hline Speed $(\mathrm{km} / \mathrm{h})$ & Air drag force $(\mathrm{N})$ \\
\hline 10 & 0.47 \\
20 & 1.90 \\
40 & 7.48 \\
\hline
\end{tabular}

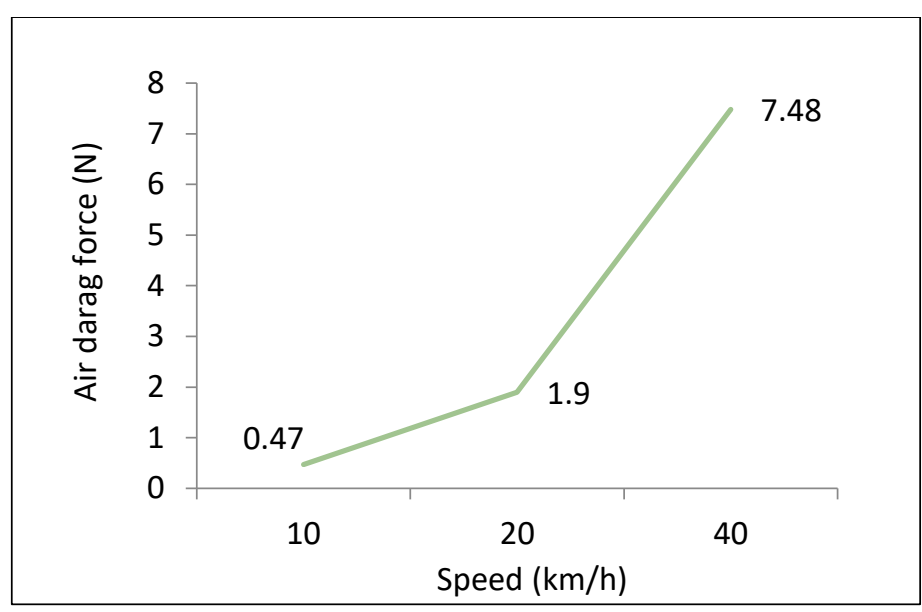

Figure 7. Graph of air drag force with variations of velocity

The table and graph above showing that air drag force will increase when the vehicle speed is an increase.

\subsection{Wheel Torque}

The wheel torque result is based on the manual calculation and dyno test result:

a. The manual calculation result of wheel torque

The result of wheel torque manual calculation is in the table below: 
Table 7. Wheel torque based on the manual calculation

\begin{tabular}{cc}
\hline $\begin{array}{c}\text { Speed } \\
(\mathrm{km} / \mathrm{h})\end{array}$ & $\begin{array}{c}\text { Wheel torque } \\
(\mathrm{Nm})\end{array}$ \\
\hline 1 & 425 \\
10 & 219 \\
13 & 218 \\
20 & 216 \\
30 & 210 \\
40 & 198 \\
50 & 174 \\
60 & 138 \\
70 & 86 \\
\hline
\end{tabular}

b. The wheel torque result base on the dyno test

The result of wheel torque based on the dyno test is in the table below:

Table 8. Wheel torque based on the dyno test

\begin{tabular}{cc}
$\begin{array}{c}\text { Speed } \\
(\mathrm{km} / \mathrm{h})\end{array}$ & $\begin{array}{c}\text { Wheel torque } \\
(\mathrm{Nm})\end{array}$ \\
\hline 1 & 2 \\
10 & 160 \\
13 & 279 \\
20 & 275 \\
30 & 268 \\
40 & 230 \\
50 & 178 \\
60 & 138 \\
70 & 104 \\
\hline
\end{tabular}

c. The table and graphic comparison

The table and graphic below is the comparation between the wheel torque based on the manual calculation and dyno test result.

Table 9. Table comparison of wheel torque

\begin{tabular}{ccc}
\hline $\begin{array}{c}\text { Speed } \\
(\mathrm{km} / \mathrm{h})\end{array}$ & $\begin{array}{c}\text { Wheel torque based on } \\
\text { the calculation }(\mathrm{Nm})\end{array}$ & $\begin{array}{c}\text { Wheel torque based on } \\
\text { the dyno test }(\mathrm{Nm})\end{array}$ \\
\hline 1 & 425 & 2 \\
10 & 219 & 160 \\
13 & 218 & 279 \\
20 & 216 & 275 \\
30 & 210 & 268 \\
40 & 198 & 230 \\
50 & 174 & 178 \\
60 & 138 & 138 \\
70 & 86 & 104 \\
\hline
\end{tabular}




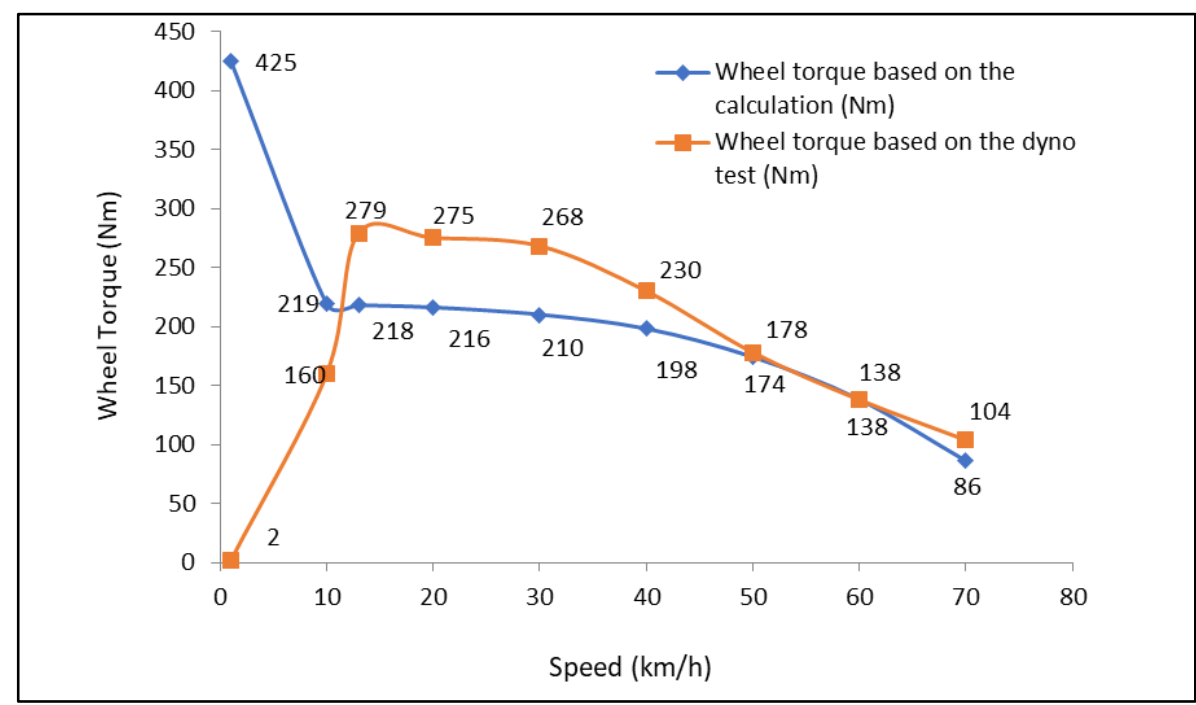

Figure 8. Graph of wheel torque comparison

\subsection{Wheel Torque Analysis Between the Manual Calculation and the Dynotest Result}

Figure 8 shows that the wheel torque from a speed of $1 \mathrm{~km} / \mathrm{h}$ to before $13 \mathrm{~km} / \mathrm{h}$ differs between the wheel torques based on the calculations and the dyno tests. The wheel torque based on the dyno test shows that the wheel torque starts from small to high torque and this is because the pressing process of the accelerator pedal cannot be directly fully depressed so that the electric current supplied to the motor is starting from the small to high. The peak wheel torque based on the dyno test appears at speed of $13 \mathrm{~km} / \mathrm{h}$ with torque is $279 \mathrm{Nm}$.

The wheel torque at speed of $13 \mathrm{~km} / \mathrm{h}$ to $70 \mathrm{~km} / \mathrm{h}$ based on the graph of figure 8 showing that the number of torque based on the dyno test is higher than based on the manual calculation because the wheel of the electric car is always against the roller load during running and no any pushing force support like driving on the normal asphalt road.

\section{Conclusion}

From the results of the research and analysis above, this research concludes as follows:

a. The strength of the frame structure simulated using ANSYS software the safety factor of the frame with a load of $243 \mathrm{~kg}$ is 15.

b. The air drag force at a speed of $10 \mathrm{~km} / \mathrm{h}$ is $0.47 \mathrm{~N}$, a speed of $20 \mathrm{~km} / \mathrm{h}$ is $1.90 \mathrm{~N}$, and a speed of $40 \mathrm{~km} / \mathrm{h}$ is $7.48 \mathrm{~N}$.

c. The wheel torque based on the dyno test at speed of $1 \mathrm{~km} / \mathrm{h}$ is $2 \mathrm{Nm}$, speed of $10 \mathrm{~km} / \mathrm{h}$ is 160 $\mathrm{Nm}$, speed of $20 \mathrm{~km} / \mathrm{h}$ is $275 \mathrm{Nm}$, speed of $30 \mathrm{~km} / \mathrm{h}$ is $268 \mathrm{Nm}$, speed of $40 \mathrm{~km} / \mathrm{h}$ is $230 \mathrm{Nm}$, speed of $50 \mathrm{~km} / \mathrm{h}$ is $178 \mathrm{Nm}$, speed of $60 \mathrm{~km} / \mathrm{h}$ is $138 \mathrm{Nm}$, and speed of $70 \mathrm{~km} / \mathrm{h}$ is $104 \mathrm{Nm}$. The peak wheel torque occurs at a speed of $13 \mathrm{~km} / \mathrm{h}$ is $279 \mathrm{Nm}$.

\section{Acknowledgments}

The authors would like to thank to RISTEK-BRIN \& Universitas Mercu Buana for their support through the founding of this research.

\section{References}

[1] Huda, M., Aziz, M., \& Tokimatsu, K. (2019). The future of electric vehicles to grid integration in Indonesia.

[2] Jiang, J., \& Zhang, C. (2015). Fundamentals and application of lithium-ion batteries in electric drive vehicles. In Fundamentals and Application of Lithium-ion Batteries in Electric Drive Vehicles [3] Kim, S.-H. (2017). Electric Motor. In Electric Motor Control.

[3] Larminie, J., \& Lowry, J. (2003). Electric Vehicle Technology Explained. In Electric Vehicle Technology Explained [4] Chau, K. T. (2015). Electric vehicle machines and drives: Design, analysis and application. In Electric Vehicle Machines and Drives: Design, Analysis and Application.

[4] Huang, C., Lei, F., Han, X., \& Zhang, Z. (2019). Determination of modeling parameters for a brushless 
DC motor that satisfies the power performance of an electric vehicle. Measurement and Control (United Kingdom), 52(7-8), 765-774.

[5] Chau, K. T. (2015). Electric vehicle machines and drives: Design, analysis and application. In Electric Vehicle Machines and Drives: Design, Analysis and Application.

[6] Noor Azreen Bin Hamzah (2015). Design and Analysis of Space Frame Chassis.

[7] Brown, W. (2002). Brushless DC Motor Control Made Easy. 1-48.

[8] Kim, S.-H. (2017). Electric Motor. In Electric Motor Control.

[9] Ramesh, M. V., Rao, G. S., Amarnath, J., Kamakshaiah, S., \& Jawaharlal, B. (2011). Speed torque characteristics of brushless DC motor in either direction on load using ARM controller. 2011 IEEE PES International Conference on Innovative Smart Grid Technologies-India, ISGT India 2011.

[10] Braun, J. (2012). Formulae Handbook. academy.maxonmotor.ch 